\title{
Pola Hidup Sehat dan Penyusunan Menu Sehat dalam Masa New Normal Covid-19 kepada Dharma Wanita Pegawai Negeri Sipil Badan Pusat Statistik Simalungun
}

\author{
Ani Sutiani ${ }^{1)}$, Rini Selly ${ }^{2)}$, Tyas Permatasari ${ }^{3)}$, Marini Damanik ${ }^{4)}$ \\ Universitas Negeri Medan ${ }^{1)}$ \\ Universitas Negeri Medan ${ }^{2}$ \\ Universitas Negeri Medan ${ }^{3)}$ \\ Universitas Negeri Medan ${ }^{4)}$ \\ corresponding author : asr.sutiani@gmail.com
}

\begin{abstract}
ABSTRAK
Pengenalan pembelajaran online sebagai bentuk pengabdian kepada masyarakat oleh Balai Penelitian dan Pengabdian Universitas Negeri Medan dengan sosialisasi life skill untuk mendapatkan hidup sehat dan penyiapan menu sehat di era New Normal Covid-19 telah dilaksanakan secara sipil. Serikat Pekerja Istri, Badan Pusat Statistik Simalungun. Pengenalan pembelajaran online sebagai bentuk pengabdian kepada masyarakat oleh Balai Penelitian dan Pengabdian Universitas Negeri Medan dengan sosialisasi life skill untuk mendapatkan hidup sehat dan penyiapan menu sehat di era New Normal Covid-19 telah dilaksanakan secara sipil. Persatuan Istri Pembantu Badan Pusat Statistik Kabupaten Simalungun. Dalam pertemuan tersebut, tidak hanya pengenalan ruang kelas Google tetapi juga pedoman gaya hidup sehat yang disosialisasikan. Kebutuhan nutrisi selama periode COVID -19 normal baru diusulkan di akhir. Program pembelajaran online dan offline. Hampir 80\% peserta akrab dengan Google Kelas. Namun mengenai konten, tampilan, dan fungsi dari google classroom sendiri, sebagian besar peserta kurang paham. Apalagi, sekitar 75\% peserta telah mengaplikasikan piring makan mereka sebagai tugas yang harus dikumpulkan melalui Google Classroom. Menu sehat pada sajian yang dikonsumsi para peserta setiap hari. Waktu penelitian terbatas, jadi ini hanya membutuhkan beberapa bagian dari studi google kelas. Kegiatan pengabdian masyarakat ini berlangsung sukses karena peserta merasa puas. Mereka tahu metode google classroom, pedoman gaya hidup sehat dan, nutrisi perlu persiapan selama COVID-19 normal yang baru.
\end{abstract}

Kata kunci: Google classroom, gaya hidup sehat, menu sehat, normal baru, COVID 19

\begin{abstract}
The introduction of online learning as a form of community service by the Medan State University Research and Service Institute with the socialization of life skills to get a healthy life and the preparation of a healthy menu in the New Normal Covid-19 era has executed at civil servant wife union, Central Bureau of Statistics in Simalungun. The introduction of online learning as a form of community service by the Medan State University Research and Service Institute with the socialization of life skills to get a healthy life and the preparation of a healthy menu in the New Normal Covid-19 era has executed at civil servant wife union, Central Bureau of Statistics in Simalungun district. During the meeting, not only the introduction of Google classroom but also the guidelines for a healthy lifestyle socialized. The nutrition needs during the new normal COVID - 19 period was proposed at the end. Online and offline learning program. Almost $80 \%$ of participants are familiar with Google Classroom. However, regarding the content, appearance, and function of the google classroom itself, most of the participants did not understand well. Moreover, about $75 \%$ of participants have applied their dinner plate is a task that must be collected through Google Classroom. A healthy menu on a dish that is consumed by the participants every day. The time of research was limit, so it just takes some part of google classroom studies. The community service activity was successful because the participant feels satisfied. They knew to google classroom methods, guidelines for a healthy lifestyle and, the nutrition needs preparation during the new normal COVID-19.
\end{abstract}

Keywords: Google classroom, healthy lifestyles, healthy menu, new normal, COVID 19 


\section{PENDAHULUAN}

Pandemi infeksi virus corona atau Covid-19 memaksa semua orang untuk beradaptasi, termasuk para guru. Sekolah boleh saja tutup, tapi kegiatan belajar mengajar harus dilanjutkan. Siswa terus melakukan semua pekerjaan sekolah walaupun di rumah. Pembelajaran online telah digaungkan sebagai solusi. Hanya saja pembelajaran online tidak semudah yang dibayangkan. Tidak semua anak bisa mengaksesnya karena ada orang tua yang masih bekerja, ada juga orang tua yang belum paham teknologi, sehingga kurang lancar dalam menggunakan aplikasi. Meski terlihat menyenangkan, belajar di rumah bukanlah hal yang mudah bagi para orang tua. Orang tua yang juga bekerja dari rumah diminta untuk mengawasi pembelajaran anak selama di rumah.

Selama belajar di rumah, sistem pembelajaran di sekolah anaknya masih seperti biasa. Perbedaannya hanya melalui kelas online, biasanya melalui media sosial (WhatsApp, Facebook, YouTube, dan Instagram) dan media pembelajaran online (e-learning) seperti: Google Classroom, Zoom, Webex, dan Schoology.

Pengetahuan tentang pembelajaran online maupun game online harus diketahui oleh orang tua / ibu. Dalam hal ini, orang tua / ibu dapat memanfaatkan semua yang ditawarkan internet sekaligus meminimalkan potensi bahaya saat menghadapi krisis kesehatan seperti COVID-19. Krisis kesehatan bisa diatasi dengan menyiapkan menu sehat untuk meningkatkan kekebalan dalam menghadapi pandemi Covid 19.
Sedangkan orang tua/ibu juga harus memberikan pendidikan kecakapan hidup terkait pandemi COVID-1 sesuai SE No. 4 tahun 2020.

Kemudian menghadapi krisis kesehatan seperti COVID-19. Makan makanan bergizi seimbang sebaiknya dilakukan saat makan utama atau saat makan camilan. Dengan demikian, tubuh bisa mendapatkan lebih banyak nutrisi yang dibutuhkan tubuh untuk menjaga kekebalan. Hal itu bisa lebih mudah dipenuhi dengan menyiapkan menu sehat untuk mengatasi COVID-19 terlebih dahulu.

\section{METODE PELAKSANAAN}

Berdasarkan permasalahan yang mengemukakan dalam kegiatan PKMBOPTN ini, program pembelajaran online dan offline. Metode pendekatan yang digunakan adalah metode pendidikan, pelatihan, sosialisasi, dan pendampingan.

1. Mengamati kondisi bisnis mitra kerja untuk mengidentifikasi permasalahan yang dihadapi terkait permasalahan pembelajaran online yang dihadapi orang tua / ibu pada saat pandemi virus COVID-19.

2. Melakukan pelatihan berupa pengenalan pembelajaran online, strategi edukasi peningkatan life skill khususnya yang berkaitan dengan PHBS, serta penyiapan menu sehat menghadapi pandemi COVID-19 yang dibutuhkan pasangan.

3. Melakukan sosialisasi dan pendampingan pelatihan pembelajaran online, meningkatkan strategi life skill, 
dan menyiapkan menu sehat dalam menghadapi pandemi virus COVID 19.

\section{HASIL DAN PEMBAHASAN}

Pengenalan pembelajaran online sebagai bentuk pengabdian kepada masyarakat oleh lembaga penelitian dan pengabdian universitas negeri Medan dengan sosialisasi life skill berupa pola hidup sehat dan penyiapan menu sehat dalam menghadapi New Normal Covid19 dilaksanakan di Dharma Wanita Pegawai Negeri Sipil Badan Pusat Statistik di kabupaten Simalungun. Pertemuan pertama adalah Forum Group Discussion (FGD) yang dilaksanakan secara online pada $10 \mathrm{Juli}$ 2020, oleh tim pengabdian Lembaga Penelitian dan Pengabdian Universitas Negeri Medan bersama Dharma Wanita Pegawai Negeri Sipil Badan Pusat Statistik di kabupaten Simalungun. Dalam petemuan online tersebut, hadir 25 ibu yang merupakan anggota Dharma Wanita Pegawai Negeri Sipil 1 BPS Simalungun dan empat dosen FMIPA UNIMED yang merupakan tim dari LPPM Unimed.

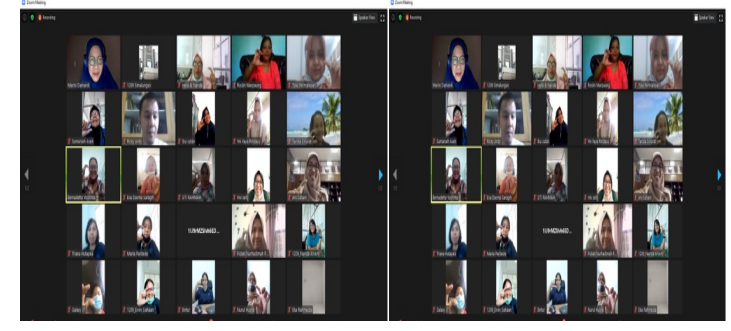

Gambar 1. Forum Diskusi Kelompok sosialisasi pembelajaran google classroom, kecakapan hidup sehat, dan penyiapan menu sehat saat pandemi Covid-19.

Dalam acara FGD kali ini, pengenalan pembelajaran online yang disosialisasikan oleh Ibu Rini Selly, S.Pd., M.Sc. Kemudian disosialisasikan pedoman pembinaan perilaku hidup bersih dan sehat melalui penggunaan masker, hand sanitizer, dan menjaga jarak oleh Ibu Dr. Ani Sutiani, M.Si serta penjelasan pemenuhan gizi selama periode Covid -19 normal baru. Penjelasan pemenuhan gizi pada masa pandemi Covid-19 oleh Tyas Permatasari lebih ditekankan pada konsumsi vitamin yang berfungsi sebagai antioksidan dalam mencegah penyebaran virus Covid-19, seperti vitamin $\mathrm{C}$.



Gambar 2. Presentasi Tyas tentang vitamin C

Selanjutnya, pada pertemuan kedua, tim mengunjungi Dharma Wanita Badan Pusat Statistik Kabupaten Simalungun pada tanggal 25 Agustus 2020. Pelatihan pembelajaran google classroom offline dilakukan dengan mengikuti standar pembelajaran operasional selama pandemi Covid-19. Berdasarkan pretest yang dilakukan pada ibu terkait google classroom, hampir $80 \%$ ibu sudah mengenal google classroom. Namun mengenai konten, tampilan, dan fungsi dari google classroom sendiri, banyak ibu yang kurang paham. 


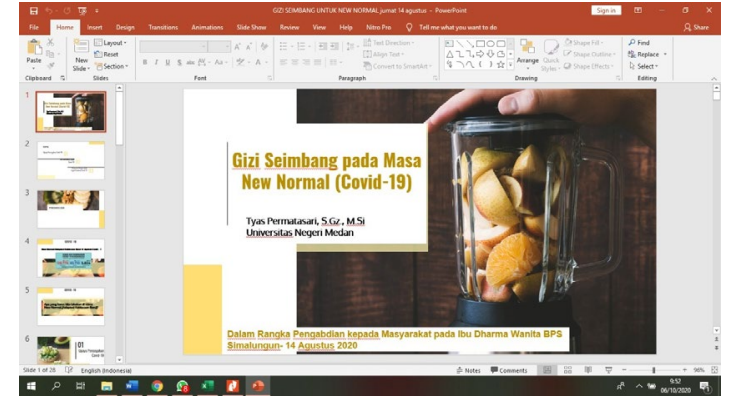

Gambar 3. Presentasi Tyas tentang gizi seimbang selama New Normal (Covid-19)

Di hari yang sama, pelatihan penyiapan menu sehat untuk ibu dilakukan secara online dengan menerapkan pembelajaran google classroom melalui google meet selama pandemi ini. Para dharma betina memiliki antusias yang tinggi terhadap gizi seimbang untuk bertahan hidup dari virus Corona baru. Sekitar 75\% telah mengaplikasikan piring makan saya. Sebuah gambar menu sehat di atas piring yang dikonsumsi oleh para wanita Dharma Wanita setiap hari yang merupakan tugas yang harus dikumpulkan melalui Google Classroom.

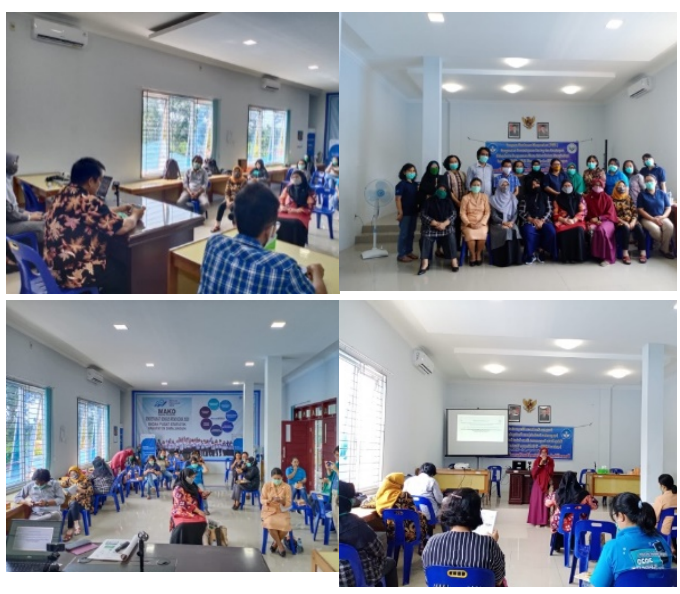

Gambar 4. Beberapa foto kegiatan belajar di Google classroom bersama ibu-ibu Dharma Wanita di BPS Simalungun.

\section{KESIMPULAN}

Berdasarkan pretest yang dilakukan Pada ibu terkait google classroom, hampir 80\% ibu sudah mengenal google classroom. Namun mengenai konten, tampilan, dan fungsi dari google classroom sendiri, banyak ibu yang kurang paham. $\quad 75 \%$ telah mengaplikasikan gambar menu sehat di piring yang dikonsumsi ibu-ibu dharma wanita setiap harinya yang merupakan tugas yang harus dikumpulkan melalui google classroom.

\section{UCAPAN TERIMA KASIH}

Dharma Wanita Pegawai Negeri Sipil, Badan Pusat Statistik Simalungun dan Tim Pengabdian Masyarakat LPPM Unimed.

\section{REFERENSI}

Sudirman Siahaan.E-Learning (Pembelajaran Elektronik) Sebagai Salah Satu Alternatif Kegiatan Pembelajaran, (http://www.Depdiknas.go.id)

Johnson, Elaine B.Contextual Teaching and Learning: Menjadikan Kegiatan Belajar dan Mengajar Mengasyikkan dan Bermakna, Bandung: Ujungberung, 2007.

Anwar. Pendidikan Kecakapan Hidup. Bandung: Alfabeta,2006.

Nuryanto,dkk.Pengaruh pendidikan gizi terhadap pengetahuan dan sikap tentang gizi anak Sekolah Dasar. Jurnal Gizi Indonesia (ISSN : 1858-4942) Vol. 3, No. 1, Desember 2014.

Sitiatava Rizema. Pengantar Ilmu Gizi dan Diet. Jogjakarta. DMedika,2013. 
Soekirmaan, Et al. Hidup sehat, Gizi seimbang dalam siklus kehidupan manusia. Jakarta.Primamedia Pustaka,2010. 